IRA-International Journal of Management \&

Social Sciences

ISSN 2455-2267; Vol.10, Issue 01 (January 2018)

Pg. no. 1-15

Institute of Research Advances

http://research-advances.org/index.php/RAJMSS

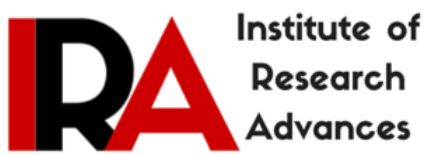

\title{
Implication of Climate Change on the Livelihood of Rural Farmers - An Enquiry
}

\author{
Dr. R. Dayanandan \\ Professor, Hawassa University, ETHIOPIA .
}

Type of Review: Peer Reviewed.

DOI: http://dx.doi.org/10.21013/jmss.v10.n1.p1

How to cite this paper:

Dayanandan, R.. (2018). Implication of Climate Change on the Livelihood of Rural Farmers - An Enquiry. IRA-International Journal of Management \& Social Sciences (ISSN 2455-2267), 10(1), 1-15. doi:http://dx.doi.org/10.21013/jmss.v10.n1.p1

(C) Institute of Research Advances.

\section{(cc) BY-No}

This work is licensed under a Creative Commons Attribution-Non Commercial 4.0 International License subject to proper citation to the publication source of the work.

Disclaimer: The scholarly papers as reviewed and published by the Institute of Research Advances (IRA) are the views and opinions of their respective authors and are not the views or opinions of the IRA. The IRA disclaims of any harm or loss caused due to the published content to any party.

Institute of Research Advances is an institutional publisher member of Publishers Inter Linking Association Inc. (PILA-CrossRef), USA. The institute is an institutional signatory to the Budapest Open Access Initiative, Hungary advocating the open access of scientific and scholarly knowledge. The Institute is a registered content provider under Open Access Initiative Protocol for Metadata Harvesting (OAI-PMH).

The journal is indexed \& included in WorldCat Discovery Service (USA), CrossRef Metadata Search (USA), WorldCat (USA), OCLC (USA), Open J-Gate (India), EZB (Germany) Scilit (Switzerland), Airiti (China), Bielefeld Academic Search Engine (BASE) of Bielefeld University, Germany, PKP Index of Simon Fraser University, Canada. 


\begin{abstract}
Climate change and variability worsened the situation by increasing moisture stress in the growing seasons of most cereal crops. Agricultural production among the farming rural adults in the country is adversely affected by climate change. As a result of this, the livelihood of large numbers of the rural poor is at risk and their vulnerability to food insecurity will be increased. Though many interventions are undertaken by different stakeholders, still the problem is worsening in the study area. Hence the main focus of this paper is assessing the climatic characteristics and the effects of climate change on the livelihood of rural farmers in the study area. To achieve the objectives, relevant data was collected from 123 sample rural farmers from three villages through stratified random sampling technique based on the agro-ecological conditions. In addition, focus group discussion and key informant interview were also carried out to elicit the relevant information. The collected data was analysed using descriptive statistics such as mean, percentages and standard deviation while inferential statistics like multiple linear regression and correlation to determine the effect of climate on the status of livelihood. The major findings reveal that there is high perception of farmers about climate change and mainly the factors which affecting were found to be population growth, overgrazing, deforestation, improper land use, etc. Some elements of climate, temperature, rainfall and humidity show inter annual and seasonal variability with slightly increasing trend. The study recommends that awareness creation on climate mitigation strategies, diversifying the livelihood options, capacity building through training to adopt different technologies is essential.
\end{abstract}

Key words: Climate change, livelihoods, variability, climate adaptation

\title{
1. Background and Statement of the Problem
}

Global ecology is degrading through time because of human socioeconomic activities that have direct impact on the environment. In addition to industries and factories, the natural environment is also overused, polluted and dwindled especially since the last century because of increased and extensive commercial farming. Rapid population growth has resulted in deforestation of natural vegetation for the sake of new settlements and farms expansion. These anthropogenic activities have resulted in a perceivable climatic change (ISET, 2013).

In recent times, the issues of climate change have become one of the key environmental and development dialogue among the scientists, politicians and development thinkers. Although a few skeptics remain, there is remarkable scientific consensus that global climate change is occurring. Many thinkers and writers including the scientists working with the Intergovernmental Panel on Climate Change have concluded that these changes are already under way (Dawit and Habtamu, 2011).

Over the coming decades, global climate change will have an impact on food and water security in significant and highly uncertain ways, and there are strong indications that developing countries will withstand the worst of the adverse consequences, particularly from climate change. This is largely because poverty levels are high, and developing-country capacity to adapt to global change is weak. Furthermore, the rural populations of developing countries - for whom agricultural production is the primary source of direct and indirect employment and income will be most affected due agriculture's vulnerability to global change processes (Ringler, 2011).

The negative effects of climate change are threatening to reverse development gains in many parts of the world particularly for subsistence farmers and in Sub-Saharan Africa. In the Sub-Saharan region, rainfall patterns have become less predictable, precipitation has decreased and will be severely compromised on average and temperatures are rising (Holmgren and Oberg, 2006). Evidence shows that the upward trend of the already high temperatures and the reduction of precipitation levels will increasingly result in reduced agricultural production due to the carbon effect and the worming climate in Sub-Sahara Africa (Mano \& Nhemachena, 2007).

Smallholders in many parts sub-Saharan Africa generally face widespread problems related to inappropriate cultivation, overgrazing and deforestation, resulting soil erosion and soil fertility decline, also water scarcity, lack of pasture and livestock feed and the fuel wood crisis. There is much concern that the fragile African ecosystems (mountains, dry lands and Coastal areas) will undergo noticeable changes under future climate scenarios (FAO, 2011).

Agriculture plays a central role in the economic and social life of the people of Ethiopia and smallholder farmers produce $90 \%$ of the total yield of agricultural sector while $99 \%$ of the production comes from the rain fed agriculture, which is highly sensitive to climate change and variability. This sector employs about 80-85 per cent of 
working population and contributes about 40-50 per cent of total GDP with livestock and livestock products accounting for about 20 per cent of agricultural GDP (Climate Policy | Irish Aid | September2016). The dependency of most of the farmers on rain fed agriculture has made the country's agricultural economy extremely vulnerable to the adversities of weather and climate. Agriculture in the country is exposing to the effect of failure of rains or occurrence of successive dry spells during the growing season, which could lead to food shortage (MoFED, 2010).

Ethiopia is one of the countries that have fewer emissions but experience climatic changes due to the high emissions coming from other world neighbors. Large parts of Ethiopia are seriously threat by climate change, which contributes to frequent drought, flooding, rising average temperatures and diseases. Climate issues continue to pose a significant challenge in Ethiopia by affecting food security, health, water and energy supply, poverty reduction and sustainable development efforts, as well as by causing natural resource degradation and natural disasters. These extreme events affect livelihoods, especially those of the poor - the impacts of past droughts such as that of the 2002/03 are still fresh in the memories of many Ethiopians climate change research center (IPCC, 2010).

The effects of climate change on the livelihood of the southern part felts in various agro ecologies according to the survey studies (eg. Temesgen, 2010). They found that the rural communities livelihood is comprised of the assets (natural, physical, human, financial and social capital), the activities and the access to these (mediated by institutions and social relations) that together determine the living gained by the individuals or households. These are directly or indirectly affect by the status of climate of the region.

Livelihood in the region, therefore, is determined by the climatic, environmental and ecological changes, which affect the economic activities of the farming households. These households start off with certain assets, have potential access to others, and using these, engage in a range of economic activities, get certain results (food, cash, other resources) and this determine their standard of living (Ellias, 2010).

Current climate variability, especially the cycles of drought and famine in Ethiopia are worsening the life of its population socioeconomically and is facing a number of critical development problems due to ecosystem management challenges that affect the lives and livelihoods of its farmers and pastoralists. Without urgent action, this condition is presumably devastating to natural environment and destroy livelihood of the people especially the rural farming and pastoralist communities due to the increasing high degradation, rapid population growth, sharp decrease in grazing land and increasing food and energy shortages are identified as the major development challenges in Ethiopia (Kindu, 2013).

The study area is one of the agricultural crops producing areas and the farmers in the district practice mixed farming in most parts of different ecological zones. There is competition for the scarce resources among the community that led to clearing of forest and expansion of farming activities in all riverbanks.

Like most rural areas of Ethiopia, the study district is characterizing by fragile natural resource base, shortage of agricultural land and speedy deforestation and high land degradation in most of its highlands. The natural vegetation is extensively deforested since the last twenty years, which has resulted in drying small rivers that come out from highland forests. The livelihood of farming households is adversely affected by climate change and their vulnerability to food insecurity has increased. Crop and livestock production is affect due to the change in the pattern and timing of rainfall (Agricultural and Rural Development Annual Report, 2016).

One of the bottlenecks in development in the study district is lack of suitable research to address the existing problems of climatic change and no empirically informed and practically guided efforts to help them mitigate or avoid the problems of backward farming systems. The magnitude and types of climatic change effects, or the adverse impacts of climate change and its variability on the livelihood of the farming community are not yet determined by any sound research.

The lack of such study in the area has limited the creation of possible policy and programmatic frameworks and affected the understanding and application of appropriate adaptation measures. Hence this research paper aimed to contribute to the empirical gap prevalent in the study area 


\section{Specific objectives}

1. To analyze the level of change in temperature and rainfall for the last decade in the study district

2. To identify the causes of climatic change in the selected district

3. To explore the effects of climate change on livelihood of subsistence farmers in the study area; and

4. To trace out climate change adaptation or coping activities that exists in the study area

5.

\section{Research Methodology}

This is a descriptive one based on both primary and secondary data incorporating qualitative and quantitative approaches. Primary data was collected from rural farming households and secondary time series data on climatic conditions were collected from Meteorological Agency. To address the objectives, two rural villages from high lands and one village from mid land were selected purposively from the study district. There are 1923 subsistence farms are found in the three sample villages. To arrive the sample size of 113 of farmers, Yamane (1967) formula was used. Finally the arrived sample size was distributed to the sample villages by proportionate sampling techniques. In addition, the researcher added ten more farmers with the expectation of non-response rate and the total sample size is 123. Semi structured interview schedule was used to generate information regarding socio economic condition, perception of farmers towards climate change and variability in their locality, adverse effects of climate change on farmers' livelihoods and their coping mechanisms. In addition, key informants' interview and focus group discussion were also carried out to elicit necessary information. The collected data was analysed using SPSS (version 21) to arrive the meaningful results. Descriptive statistics such as percentages, mean, standard deviation and inferential statistics such as multiple regression and correlation analyses were carried out to assess the effect of climate on the livelihood status of the farmers.

Before applying the model, existence of multi-collinearity problem was checked through Variance Inflation Factors (VIF) and no such problem was found. The dependent variable of the model is change of livelihood and the explanatory variables such as rapid growth in population, Overgrazing, Deforestation for agriculture expansion, Burning of forest for charcoal, and Improper use of farmland which are considered as the causes of climate change.

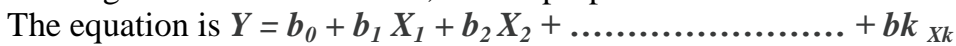

\section{Results and Discussion}

\subsection{Scio-Demographic Characteristics of Respondents}

The socio-demographic background of rural farmers is believed to have great influence in determining their placement and believed to have some implications for climate change adaptation and livelihoods development.

Table 1: Socio-demographic characteristics of Respondents

\begin{tabular}{|c|c|c|c|}
\hline Variables & Category & $\begin{array}{c}\text { Number of } \\
\text { Respondents }\end{array}$ & Percentage \\
\hline \multirow{4}{*}{ Age Category } & $21-40$ years & 70 & 60 \\
\hline & $41-60$ years & 43 & 35 \\
\hline & $>61$ years & 10 & 05 \\
\hline & Total & 123 & 100 \\
\hline \multirow{3}{*}{ Sex } & Male & 74 & 60 \\
\hline & Female & 49 & 40 \\
\hline & Total & 123 & 100 \\
\hline \multirow{5}{*}{ Marital Status } & Single & 06 & 05 \\
\hline & Married & 86 & 70 \\
\hline & Divorced & 12 & 10 \\
\hline & Widowed & 19 & 15 \\
\hline & Total & 123 & 100 \\
\hline \multirow{4}{*}{ Family Size } & $<3$ members & 12 & 10 \\
\hline & $3-5$ members & 49 & 40 \\
\hline & $>5$ members & 62 & 50 \\
\hline & Total & 123 & 100 \\
\hline \multirow[b]{4}{*}{ Educational Level } & No formal education & 65 & 53 \\
\hline & Formal education up to preparatory & 35 & 28 \\
\hline & Post high school certificate & 6 & 5 \\
\hline & Diploma & 6 & 5 \\
\hline
\end{tabular}




\begin{tabular}{|l|l|c|c|}
\hline & Degree & 11 & 9 \\
\cline { 2 - 4 } & Total & $\mathbf{1 2 3}$ & $\mathbf{1 0 0}$ \\
\hline \multirow{4}{*}{ Household farm land size } & $<$ hectare & 31 & 25 \\
\cline { 2 - 4 } & $1-2$ hectares & 80 & 65 \\
\cline { 2 - 4 } & $>3$ hectares & 12 & 10 \\
\cline { 2 - 4 } & Total & $\mathbf{1 2 3}$ & 29 \\
\hline \multirow{5}{*}{ Annual income farm activities } & $<5,000$ Birr & 43 & 35 \\
\cline { 2 - 4 } & $5,001-10,000$ Birr & 25 & 19 \\
\cline { 2 - 4 } & $10,001-15,000$ Birr & $\mathbf{1 0 0}$ & 20 \\
\cline { 2 - 4 } & $>15,000$ Birr & $\mathbf{1 0 0}$ \\
\cline { 2 - 4 } & Total & & 23 \\
\hline
\end{tabular}

Source: primary data

The survey results indicate that out of the total respondents, 35\% found within the age range of 21 to 40 years. More than half of them (60\%), are found within the age range of 41 to 60 who are considered as productive population. As the respondents' gender is concerned, more proportion of respondents $(60 \%)$ is found to be male while the rest (40\%) found to be the female. This indicates that in the study area major portion of the farmers is male category and more females in the age group of 20 to 40 years while the reverse is the case within the age range of 41 to 60 years respondents. With this adequate number of females and males who are productive, much works can be done in changing the local community's climate resilient development programs. The marital status is the other demographic variable and found that very few of the respondents (5\%) is single, $70 \%$ married, $10 \%$ divorced and $15 \%$ widowed. Regarding the family size of less than three members constitute only $10 \%$ of the whole respondents, while those with three to five members is $40 \%$ and the larger proportion of them (50\%) has a family size of more than five members.

Educational status show that respondents with no formal education constituted 53\%, while those with formal education ranging from primary to preparatory level constituted $28 \%$ of respondents. Those with achieved post high school Certificates are only 5\% and those have different types of diploma are found to be 5\% and respondents with first degree are only $9 \%$.

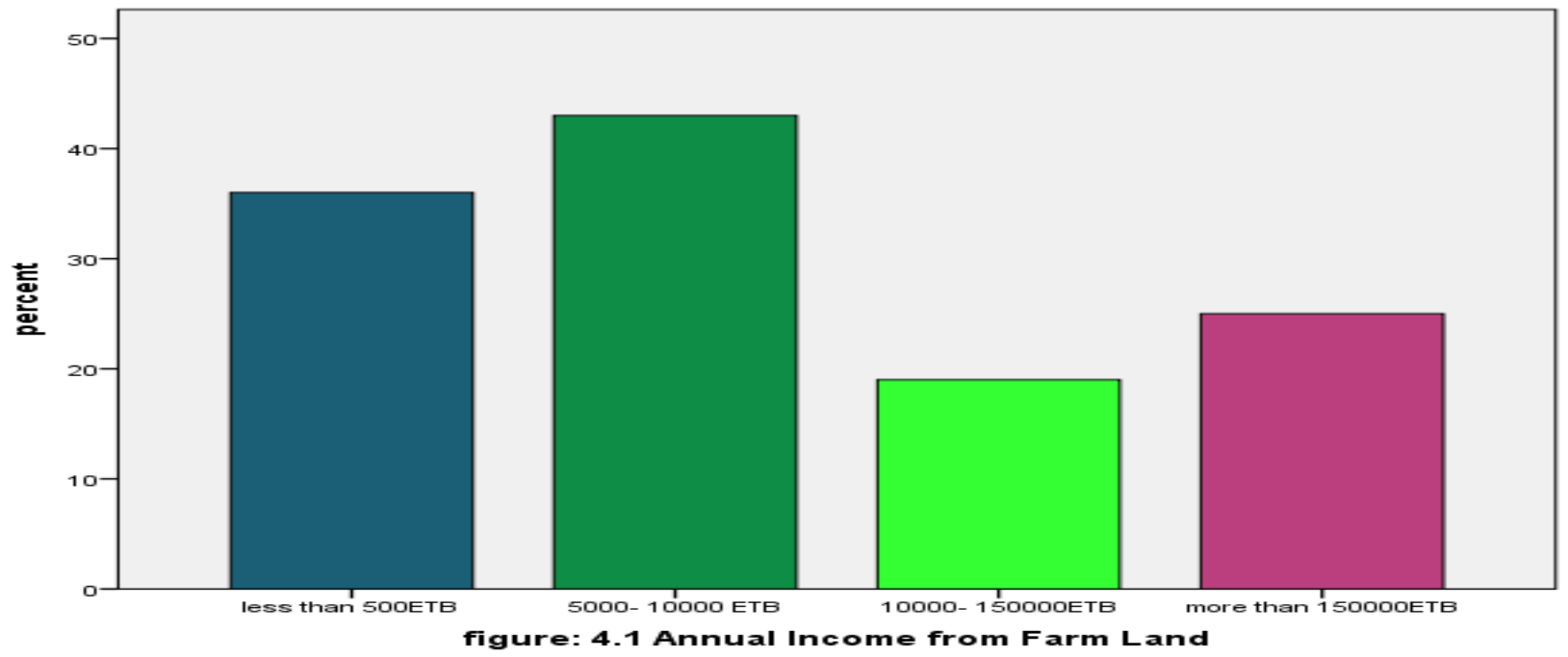

In connection to the farmland size, households with less than a hectare are $25 \%$, while those having 1 to 2 hectares are $65 \%$, majority of the respondents. However, respondents with a farmland size of more than 2 hectares are only $10 \%$. Another economic variable is the respondents' annual income from all activities and the results show that $29 \%$ of the respondents earn less than 5,000 Birr (National Currency), 35\% earn 5,000 to 10,0000 Birr, 16\% earn 10,001 to 15,000 Birr and only $20 \%$ earn more than 15,000 Birr per annum from all their farming activities. 


\subsection{Perception on climate variability and change}

The respondents were asked to indicate their perception on the change of climate and its impacts on the local household's livelihood. For this four statements were forwarded to rate them.

Table 2: Perception of climate variability and change

\begin{tabular}{|c|c|c|c|c|c|c|c|}
\hline \multirow[b]{2}{*}{ No. } & \multirow{2}{*}{$\begin{array}{l}\text { Climatic change } \\
\text { categories }\end{array}$} & \multicolumn{6}{|c|}{ Level of perception } \\
\hline & & $\mathbf{S A}$ & $\mathbf{A}$ & DA & SDA & Neutral & Total \\
\hline 1 & $\begin{array}{l}\text { The climate is perceivably } \\
\text { changed }\end{array}$ & $76(61.7)$ & $33(26.7)$ & $4(2.4)$ & $10(8.1)$ & - & $123(100)$ \\
\hline 2 & There is seasonal variability & $62(50.4)$ & $55(44.7)$ & - & $6(4.8)$ & - & $123(100)$ \\
\hline 3 & $\begin{array}{l}\text { The weather condition is } \\
\text { changed }\end{array}$ & $80(65.04)$ & $33(26.8)$ & $10(8.1)$ & - & - & $123(100)$ \\
\hline 4 & $\begin{array}{l}\text { Erratic rain is affecting crop } \\
\text { production }\end{array}$ & $68(55.2)$ & $45(36.5)$ & $10(8.1)$ & - & - & $123(100)$ \\
\hline
\end{tabular}

Source: Primary data

Note: Figures with in brackets show percentages; while SA=Strongly Agree; A=Agree; DA=Disagree; $\mathrm{SDA}=$ Strongly Disagree

It is found that, about $79 \%$ of the respondents have agreed that there is significant climate change in the study area across the past ten years. The perception of some of them (21\%) shows that they have not perceived such changes in climate. This evidently shows that there is a perceivable change in the weather condition. In support of the findings of the primary data based on the respondents' perception, the secondary data obtained from the Meteorology Agency, Southern Region office has confirmed the existence of variability in total rainfall, humidity and temperature throughout the district for 10 years (2007-2016).

\subsection{Rainfall and temperature pattern of the sample district}

Temperature and rain fall are the most important meteorological variables that indicates water scarcity, production of livestock and crop production and food production processes in countries where agriculture is more dependent on rain fall (Abebe, 2013). The average rain fall of the study district for the years 2007-2016 ranges from 191mm to $189.1 \mathrm{~mm}$ and the mean annual rain fall shown in annual variability and erratic over the past years. This variability is responsible for the problems of crop production. The idea was summarized by the information of focus group discussion participants.

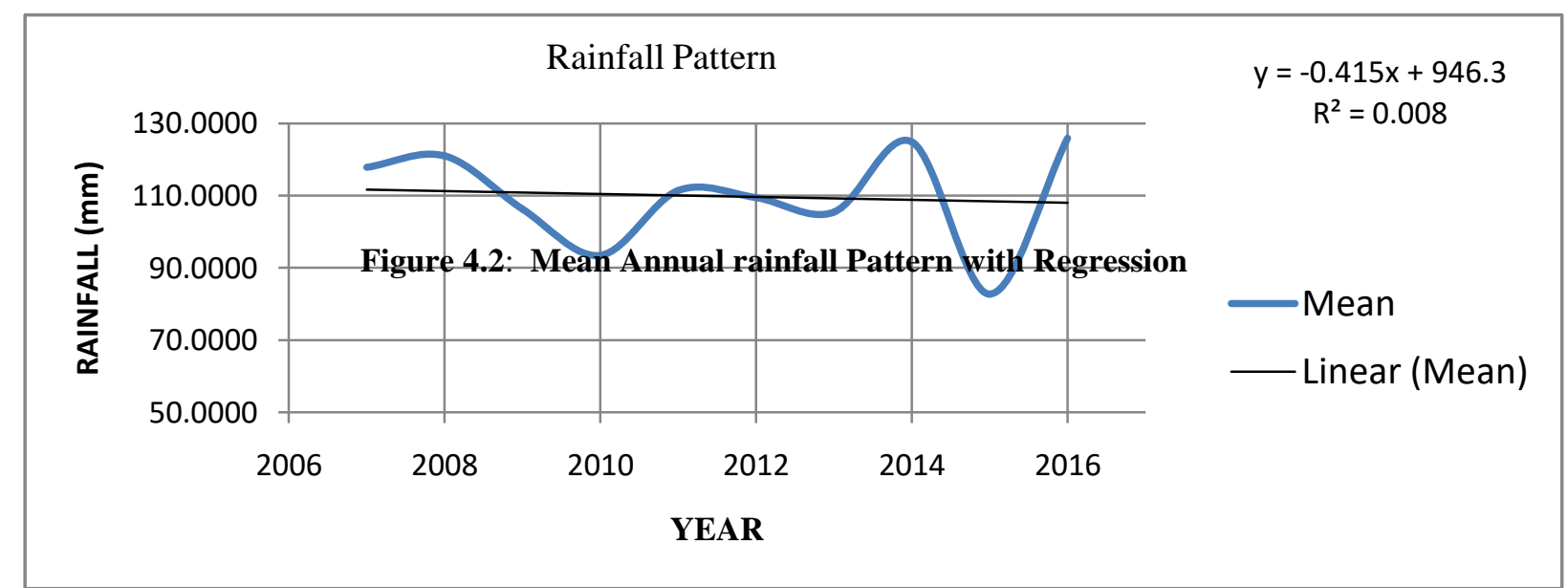

Source: National Metrological Service, 2017

The average yearly maximum temperature of the district was $25.1 \mathrm{cg}$ while the average minimum temperature was $10.06 \mathrm{cg}$. As indicated in the figure 4.3, the average maximum temperature of the district over last 10 years increased by about $1.5 \mathrm{cg}$ annually, while average minimum temperature is decreasing by 0.8 degree centigrade. 


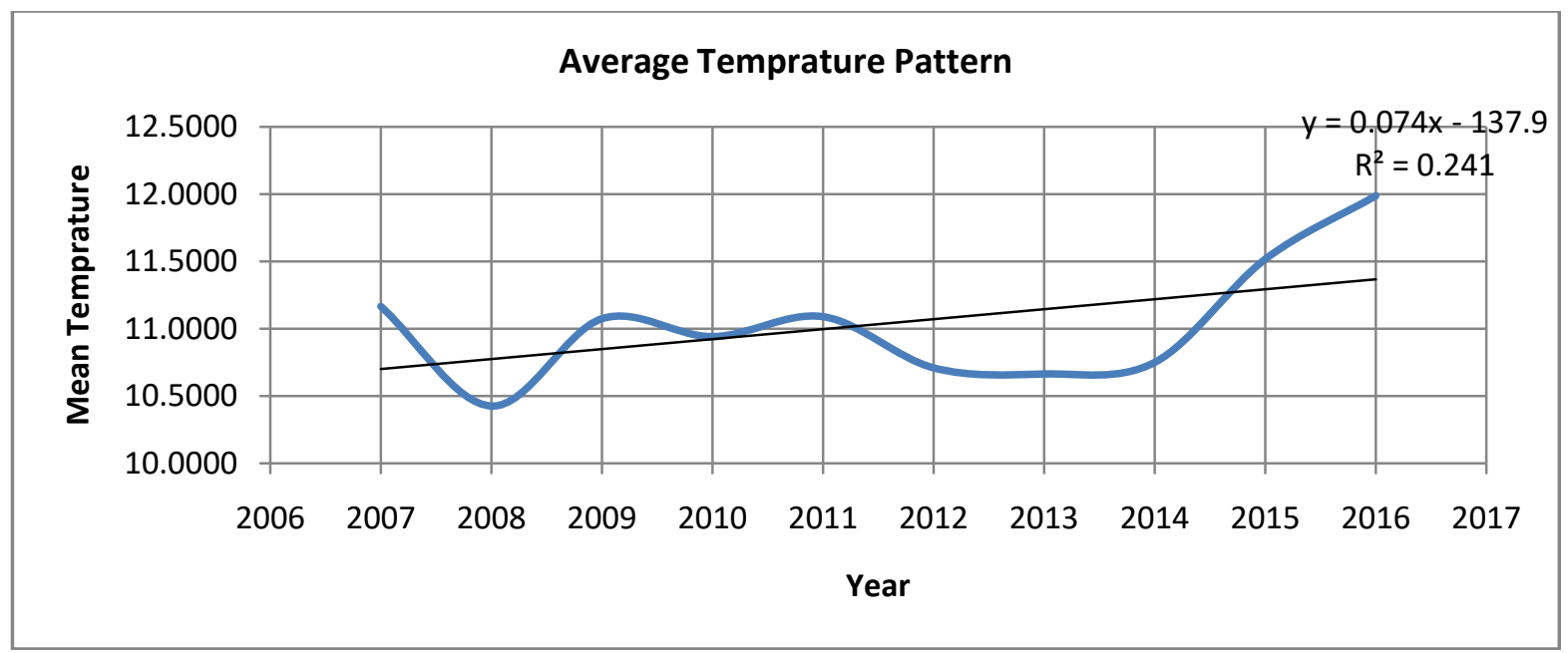

Figure 4.3: Maximum Annual temperature pattern with regression

Source: National Metrological Service, 2017

\section{Perceived causes of climate change}

Table 3: Perceived causes of climate change in the study area

Note: Figures with in brackets show percentages; while SA=strongly Agree; A=Agree; DA=Disagree;

\begin{tabular}{|c|c|c|c|c|c|c|c|}
\hline \multirow[b]{2}{*}{ No. } & \multirow[t]{2}{*}{ Perceived causes of climate change } & \multicolumn{6}{|c|}{ Respondents' Opinion } \\
\hline & & SA & $\mathbf{A}$ & DA & SDA & Neutral & Total \\
\hline 1 & Rapid growth in population & $\begin{array}{c}36 \\
(29.2)\end{array}$ & $\begin{array}{c}54 \\
(43.9)\end{array}$ & $\begin{array}{c}20 \\
(13.2)\end{array}$ & $\begin{array}{c}10 \\
(8.1)\end{array}$ & $\begin{array}{c}03 \\
(2.4)\end{array}$ & $\begin{array}{c}123 \\
(100)\end{array}$ \\
\hline 2 & Overgrazing & $\begin{array}{c}17 \\
(13.8)\end{array}$ & $\begin{array}{c}60 \\
(48.7)\end{array}$ & $\begin{array}{c}40 \\
(32.5)\end{array}$ & $\begin{array}{c}04 \\
(3.25)\end{array}$ & $\begin{array}{c}02 \\
(1.6)\end{array}$ & $\begin{array}{c}123 \\
(100) \\
\end{array}$ \\
\hline 3 & Deforestation for agriculture expansion & $\begin{array}{c}33 \\
(26.8) \\
\end{array}$ & $\begin{array}{c}30 \\
(24.3) \\
\end{array}$ & $\begin{array}{c}49 \\
(37.6) \\
\end{array}$ & $\begin{array}{c}10 \\
(8.1) \\
\end{array}$ & $\begin{array}{c}01 \\
(0.8) \\
\end{array}$ & $\begin{array}{c}123 \\
(100) \\
\end{array}$ \\
\hline 4 & Burning of forest for charcoal & $\begin{array}{c}54 \\
(43.9)\end{array}$ & $\begin{array}{c}46 \\
(37.3)\end{array}$ & $\begin{array}{c}19 \\
(15.4)\end{array}$ & $\begin{array}{c}04 \\
(3.25)\end{array}$ & - & $\begin{array}{c}123 \\
(100) \\
\end{array}$ \\
\hline 5 & Improper use of farmland & $\begin{array}{c}45 \\
(36.6) \\
\end{array}$ & $\begin{array}{c}21 \\
(17.0) \\
\end{array}$ & $\begin{array}{c}20 \\
(1.6) \\
\end{array}$ & $\begin{array}{c}34 \\
(27.6) \\
\end{array}$ & $\begin{array}{c}03 \\
(2.4) \\
\end{array}$ & $\begin{array}{c}123 \\
(100) \\
\end{array}$ \\
\hline
\end{tabular}

SDA=Strongly Disagree

Among the perceived causes of climate change, as indicated in table 3 are rapid growth of population, overgrazing, deforestation, and wrong use of farmland are given higher consensus by the respondents. These also take preeminence of perception to have been the causative factors according to majority (64\%) of the respondents. Similar studies (Sorhaug, 2011) have also attributed the causes of climate change are rapid changes in population growth and expansion of agricultural land among other things. The national and regional economic activities remain with uncontrollable effects on the ecological safety as discussed by these researchers. These studies found that the major causes for climate change in the developing regions are related to natural and economic activities through industrialization.

\subsection{Observed Indicators of climate change at Local Level}

When asked to rate and identify the indicators of climate change at the local area, as portrayed in table 4 , the respondents have agreed fairly and strongly that unpredictable rainfall, recurrent draught, increase in temperature and failing in surface water volume, decrease in humidity and changes in wind direction were identify as most perceivable indicators of climate change in the area. The weighted average of their ratings show that about $37 \%$ of respondents who agree with this fact and is followed by the other $(32 \%)$ who have strongly agreed with the same 
fact. Cumulatively, about $69 \%$ of the respondents have perceived that these indicators are overtly prevalent in the study district while others $(28 \%)$ have perceived otherwise.

Table 4: Observed Indicators of climate change at Local Level

\begin{tabular}{|l|l|c|c|c|c|c|c|}
\hline \multirow{2}{*}{ No. } & \multirow{2}{*}{$\begin{array}{l}\text { Observed indicators of climate } \\
\text { change at local level }\end{array}$} & \multicolumn{5}{|c|}{ Respondents' Opinion } \\
\cline { 3 - 7 } & & SA & A & DA & SDA & Neutral & Total \\
\hline 1 & There is unpredictable rainfall & $33(26.8)$ & $\begin{array}{c}46 \\
(37.3)\end{array}$ & $\begin{array}{c}33 \\
(26.8)\end{array}$ & $\begin{array}{c}09 \\
(7.3)\end{array}$ & $\begin{array}{c}02 \\
(1.6)\end{array}$ & $\begin{array}{c}123 \\
(100)\end{array}$ \\
\hline 2 & There is recurrent drought & $23(18.7)$ & $\begin{array}{c}46 \\
(37.3)\end{array}$ & $\begin{array}{c}42 \\
(34.1)\end{array}$ & $\begin{array}{c}12 \\
(9.7)\end{array}$ & $-\begin{array}{c}123 \\
(100)\end{array}$ \\
\hline 3 & There is increase in temperature & $39(31.7)$ & $\begin{array}{c}54 \\
(43.9)\end{array}$ & $\begin{array}{c}28 \\
(22.7)\end{array}$ & - & $\begin{array}{c}02 \\
(1.6)\end{array}$ & $(100)$ \\
\hline 4 & There is decrease in surface water & $43(34.9)$ & $\begin{array}{c}22 \\
(1.8)\end{array}$ & $\begin{array}{c}54 \\
(43.9)\end{array}$ & $-\begin{array}{c}04 \\
(3.25)\end{array}$ & $\begin{array}{c}123 \\
(100)\end{array}$ \\
\hline 5 & The humidity is decreasing & $36(29.6)$ & $(52.8)$ & $(8.1)$ & $\begin{array}{c}12 \\
(9.7)\end{array}$ & $\begin{array}{c}12 \\
123 \\
(100)\end{array}$ \\
\hline 6 & There is change in wind direction & $63(51.2)$ & $\begin{array}{c}35 \\
(28.4)\end{array}$ & $\begin{array}{c}20 \\
(16.2)\end{array}$ & $\begin{array}{c}04 \\
(3.25)\end{array}$ & $\begin{array}{c}01 \\
(8.1)\end{array}$ & $\begin{array}{c}123 \\
(100)\end{array}$ \\
\hline
\end{tabular}

Note: Figures with in brackets show percentages; while $\mathrm{SA}=$ strongly Agree; $\mathrm{A}=\mathrm{Agree}$; $\mathrm{DA}=\mathrm{Disagree}$; $\mathrm{SDA}=$ Strongly Disagree

\subsection{Climate change impact on Livelihoods}

The respondents were asked to rate their opinion in the continuum of "very high" to "very low" on the impact indicators of climate change which they have perceived. The data displayed in figure 4.5 , show that about $18 \%$ of them perceived that the impact of the climate change on their livelihood is very high in their locality while over $60 \%$ have perceived as high. A little more than $12 \%$ of them perceived as moderate. Less than $10 \%$ however have perceived otherwise that the impact of climate change in their local setting is low.

Ellias Asgera (2010) has conducted a study among farming households in Hagereselam district in which he reported related findings. The major impact assessments conducted in scenarios similar to this one have established that there is a high correlation between climate change and the status of livelihoods (Sorhaug, 2011). Further, the researcher has conducted Focus Group Discussion (FGD) comprised of 5 members from District Agriculture and Natural Resources Development office which affirmed the findings of the respondents that there is high impact of climate change on the local population's two main sources of livelihood - agriculture and livestock. The following pie chart is a display of the above finding.

घery High Impact $\quad$ High Impact $\quad$ Moderate Impact $\quad$ Low Impact

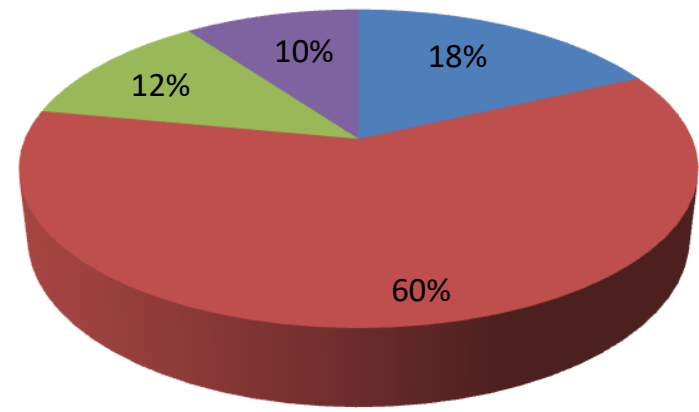

Source: Primary data

Figure 4.5: Perception of climate change impact on livelihoods 


\subsubsection{Types of livelihood sources affected in the local area}

The major sources of livelihoods that are affected in the study area was assessed and results presented in table 5 show that about $36.6 \%$ of the respondents have observed that agricultural production and pasture are very much affected due to climate variability, followed by $46 \%$ who have perceived that these two sources of livelihood are moderately affected while about $18 \%$ of them denied the fact that these two sources of livelihoods are affected.

Table 5: Types of livelihood sources affected in the local area

\begin{tabular}{|l|l|c|c|}
\hline No. & Livelihoods Affected in the Study Area & $\begin{array}{l}\text { Number } \\
\text { Respondents }\end{array}$ & Percentage \\
\hline 1 & Agricultural production and pasture are very much affected & 45 & 36.6 \\
\hline 2 & Agricultural production and pasture are moderately affected & 56 & 45.5 \\
\hline $\mathbf{3}$ & Agricultural production and pasture are not as such affected & 22 & 17.9 \\
\hline & Total & $\mathbf{1 2 3}$ & $\mathbf{1 0 0}$ \\
\hline
\end{tabular}

Source: Primary data

This shows that climate variability has affected their agricultural production and livestock pasture as reported by quite more than $80 \%$ of the respondents. The key informant's interview of three villages Agricultural and Natural Resources Development Office also attested that there is perceivable failure in agricultural productivity in the drought-affected areas in the villages since the last three to five years.

\subsection{Climate change Adaptation Activities in the Study Area}

The study also explored the climate adaptation mechanisms followed by sample respondents in their area because the actions taken by the local residents are vital for managing their livelihood Based on this, questions were raised in different ways and the responses were gathered and discussed in this section.

4.6.1 Existence of Community Based Adaptation Schemes: As indicated in figure 4.6, 43\% of them agreed that there are several community based activities aimed at climate adaptation programs, which are mobilized by the local government bodies. However, evidently higher number of them (57\%) has denied that there were such programs in which they recall to have ever been participated. Aiming to refine this finding, the researcher has brought the issue to the FGD and was able to get the insight into the matter. As it is highlighted by the discussion, it was found that there are few initiatives undertaken by government bodies at local level to respond to climate change and improve farmers' adaptability to the changing climate. However, such programs were limited in scope as very few of the residents have taken part in those programs. This indicates that there are no comprehensive and long-lasting community wide programs of climate adaptation in the study area. The initiatives that were so far implemented are found to be neither adequate nor broader in their scope in order to be taken for granted. The above data of perception of climate change adaptation can be put in a pie chart as follows.

\section{Availability of Climate Change Adaptation Activiteis}

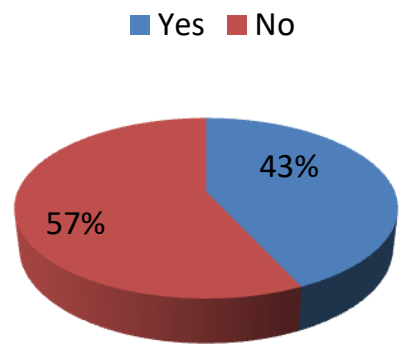

Figure 4.6: Availability of climate change Adaptation Activities

As we can see it from the chart, $43 \%$ of respondents have admitted that there is a perceivable climate change activity in their area, while majority (57\%) of the respondents, did not observe existence of any activity related to climate change adaptation. 
4.6.2 Activities related to crop production: The proportion of the respondents who took part in climate adaptation activities were asked to rate the times of activities as far as their experience and involvement with those programs are concerned. As portrayed in table $6,32.5 \%$ of the sample involved have using new varieties of crop while $24.4 \%$ of them undertaken intensive irrigation activities with the aim of adapting changes in climate. About $12.2 \%, 16.3 \%$ and $14.6 \%$ respectively using water harvesting and shifting of more drought tolerant crops and use of early maturing crops equally undertaken as it concerns their experiences. However, not every one of them have equally implemented all of these as indicate in the table 6 .

Table 6: Activities related to crop production

\begin{tabular}{|c|c|c|c|c|c|c|c|}
\hline \multirow[t]{2}{*}{ No } & \multirow{2}{*}{$\begin{array}{l}\text { Climate adaptation activities related to } \\
\text { crop production }\end{array}$} & \multicolumn{6}{|c|}{ Respondents' Opinion } \\
\hline & & SA & $\mathbf{A}$ & DA & Neutral & SDA & Total \\
\hline 1 & $\begin{array}{l}\text { Using new varieties of crop } \\
\text { production }\end{array}$ & $\begin{array}{c}24 \\
(45.2)\end{array}$ & $\begin{array}{c}12 \\
(22.6)\end{array}$ & $\begin{array}{c}07 \\
(16.9)\end{array}$ & - & $\begin{array}{c}10 \\
(18.9)\end{array}$ & $\begin{array}{c}53 \\
(100)\end{array}$ \\
\hline 2 & Shifting of more drought tolerant crops & $\begin{array}{c}17 \\
(32.0)\end{array}$ & $\begin{array}{c}14 \\
(26.4)\end{array}$ & $\begin{array}{c}22 \\
(41.5)\end{array}$ & - & - & $\begin{array}{c}53 \\
(100)\end{array}$ \\
\hline 3 & Intensive irrigation schemes & $\begin{array}{c}25 \\
(47.2)\end{array}$ & $\begin{array}{c}13 \\
(24.5)\end{array}$ & $\begin{array}{c}15 \\
(28.3)\end{array}$ & - & - & $\begin{array}{c}53 \\
(100)\end{array}$ \\
\hline 4 & Use of early maturing crops & $\begin{array}{c}44 \\
(83.0)\end{array}$ & $\begin{array}{c}05 \\
(9.4)\end{array}$ & $\begin{array}{c}04 \\
(7.5)\end{array}$ & - & - & $\begin{array}{c}53 \\
(100)\end{array}$ \\
\hline 5 & Using water harvesting management & $\begin{array}{c}30 \\
(56.6)\end{array}$ & $\begin{array}{c}13 \\
(24.5)\end{array}$ & $\begin{array}{c}06 \\
(11.3)\end{array}$ & - & $\begin{array}{c}04 \\
(7.5)\end{array}$ & $\begin{array}{c}53 \\
(100)\end{array}$ \\
\hline
\end{tabular}

Source: Primary data

Note: Figures with in brackets show percentages; while $\mathrm{SA}=$ strongly Agree; A=Agree; DA=Disagree; $\mathrm{SDA}=$ Strongly Disagree

4.6.3 Activities Related to Livestock Development: The respondents were given such variables as maintenance of pasture, plantation of innovative grasses, and existence of control grazing in their practice with climate adaptation activities mobilized by the local government bodies, and their responses are displayed in table 7 . Their overall opinion show that $44 \%$ has strongly agreed that there are all the listed activities aimed at livestock development. Still about 33\% has agreed that the stated activities were implemented in their setting. A very good number of respondents have a maintained livestock pasture, planting some innovative grasses (elephant grasses for their cows) and practicing controlled grazing in the last three to five years.

Table 7: Activities related to livestock pasture development and use

Note: Figures with in brackets show percentages; while SA=strongly Agree; A=Agree; DA=Disagree;

\begin{tabular}{|c|c|c|c|c|c|c|c|}
\hline \multirow[t]{2}{*}{ No } & \multirow{2}{*}{$\begin{array}{l}\text { Activities related to livestock } \\
\text { development }\end{array}$} & \multicolumn{6}{|c|}{ Respondents' Opinion } \\
\hline & & $\mathbf{S A}$ & $\mathbf{A}$ & DA & SDA & Neutral & Total \\
\hline 1 & $\begin{array}{l}\text { Maintenance of pasture and grass } \\
\text { cover }\end{array}$ & $16(30.0)$ & $\begin{array}{c}22 \\
(41.5)\end{array}$ & $\begin{array}{c}10 \\
(18.9)\end{array}$ & $\begin{array}{c}05 \\
(9.4)\end{array}$ & - & $\begin{array}{c}53 \\
(100)\end{array}$ \\
\hline 2 & Plantation of innovative grasses & $\begin{array}{c}20 \\
(37.8) \\
\end{array}$ & $\begin{array}{c}20 \\
(37.8) \\
\end{array}$ & $\begin{array}{c}10 \\
(18.9) \\
\end{array}$ & $\begin{array}{c}02 \\
(3.8) \\
\end{array}$ & $\begin{array}{c}01 \\
(1.9) \\
\end{array}$ & $\begin{array}{c}53 \\
(100) \\
\end{array}$ \\
\hline 3 & Planting trees of shades for livestock & $\begin{array}{c}33 \\
(62.3) \\
\end{array}$ & $\begin{array}{c}15 \\
(28.3) \\
\end{array}$ & $\begin{array}{c}5 \\
(9.4) \\
\end{array}$ & - & - & $\begin{array}{c}53 \\
(100) \\
\end{array}$ \\
\hline 4 & $\begin{array}{l}\text { Controlled grazing and pasture } \\
\text { management }\end{array}$ & $\begin{array}{c}24 \\
(45.2)\end{array}$ & $\begin{array}{c}10 \\
18.9)\end{array}$ & $\begin{array}{c}13 \\
(24.5)\end{array}$ & $\begin{array}{c}04 \\
(7.5)\end{array}$ & $\begin{array}{c}02 \\
(3.7)\end{array}$ & $\begin{array}{c}53 \\
(100) \\
(100\end{array}$ \\
\hline
\end{tabular}

SDA=Strongly Disagree

From the key informant's interview it was found that the farmers were in short supply of grazing land for their cattle, which have made the effort of many impracticable. They have noted that pasture (natural grass fields) is declining from time to time in the study area due to expansion of agriculture where some reserve fields of collective grazing were available. The interviewees also suggested that the elephant grass was not evenly distributed and some of those who have it in the last three to five years have lost its species currently which need further consideration by development extension personnel. 
4.6.4 Activities Related to Sustaining water sources and supply: As it is displayed in table 8, $9.4 \%$ of respondents have participated in recharging ground water, $28.3 \%$ have participated in the use of pounds and $62.3 \%$ are were engaged in rain water harvesting. Though the intention of the respective group of respondents is commendable, no significant efforts were adequately and consistently undertaken even among the so-called implementers of the programs. As it was suggested during the FGD, the water-harvesting program has attracted much resistance and left incomplete among many of the households. They also reflected on the problems of inadequate number of water points in the study areas, which does not exceed one or two in each village for human and animal consumption. These show that activities directed towards water resources development are at their depressing levels.

Table 8: Activities related to sustaining water sources and supply.

\begin{tabular}{|l|c|c|}
\hline \multicolumn{1}{|c|}{ Activities } & Number of Respondents & Percentage \\
\hline Use of recharging ground water & 05 & 9.4 \\
\hline Use of pounds & 15 & 28.3 \\
\hline Rain water harvesting & 33 & 62.3 \\
\hline Total & $\mathbf{5 3}$ & $\mathbf{1 0 0}$ \\
\hline
\end{tabular}

Source: Primary data

\subsubsection{Reasons for lack of Community wide Climate change Adaptation schemes}

The larger proportion of the respondents $(57 \%)$ who have detested to the existence of active and community based climate adaptation activities in the district were explained the reasons (Table 9) were believed to be the obstacles. Their responses show that, $77 \%$ of respondents have said that problems of good governance, lack of awareness and technologies are responsible for lack of strong community wide climate change adaptation schemes in the study area. However, $19.6 \%$ have denied that the reasons are not related to governance, awareness, and technology. Problems related to good governance and community inclusive development accounted for $69 \%$, lack of strong awareness creation programs geared towards climate change accounted for $70 \%$, and lack of appropriate technology accounted for $93 \%$.

Table 9: Reasons for lack of community wide climate change adaptation schemes

\begin{tabular}{|c|c|c|c|c|c|c|c|}
\hline \multirow[t]{2}{*}{ No } & \multirow{2}{*}{$\begin{array}{l}\text { Reasons for lack of community wide climate } \\
\text { change adaptation schemes }(n=70)\end{array}$} & \multicolumn{6}{|c|}{ Respondents' Opinion } \\
\hline & & SA & $\mathbf{A}$ & DA & SDA & Neutral & Total \\
\hline 1 & $\begin{array}{l}\text { Absence of good governance and community } \\
\text { inclusive development }\end{array}$ & $\begin{array}{c}18 \\
(25.7)\end{array}$ & $\begin{array}{c}30 \\
(42.8)\end{array}$ & $\begin{array}{c}20 \\
(28.5)\end{array}$ & - & $\begin{array}{c}02 \\
(2.8)\end{array}$ & $\begin{array}{c}70 \\
(100)\end{array}$ \\
\hline 2 & $\begin{array}{l}\text { Lack of awareness creation about climate change, } \\
\text { its causes and adaptation schemes }\end{array}$ & $\begin{array}{c}20 \\
(28.5)\end{array}$ & $\begin{array}{c}29 \\
(41.4)\end{array}$ & $\begin{array}{c}15 \\
(21.4)\end{array}$ & $\begin{array}{c}01 \\
(1.4)\end{array}$ & $\begin{array}{c}05 \\
(.7 .1)\end{array}$ & $\begin{array}{c}70 \\
(100)\end{array}$ \\
\hline 3 & Lack of introduction of appropriate technologies & $\begin{array}{c}32 \\
(45.7)\end{array}$ & $\begin{array}{c}33 \\
(47.1)\end{array}$ & - & $\begin{array}{c}05 \\
(7.1)\end{array}$ & - & $\begin{array}{c}70 \\
(100)\end{array}$ \\
\hline
\end{tabular}

Source: Primary data

Note: Figures with in brackets show percentages; while $\mathrm{SA}=$ strongly Agree; A=Agree; DA=Disagree; SDA=Strongly Disagree.

\subsection{Livelihood outcomes on Rural Farmers}

The overall intention of this research is to understand how the climate change affects the rural livelihood of rural farmers. Hence assessment was carried out by different indicators such as continuity of food supply, livelihood development status etc. Furthermore, the respondents have admitted that their family food supply is usually discontinued as a result of their weak livelihood basis were given another question which states, "If your family does not get food supply continuously, for how many months your family food supply is discontinued?" To this, about $22 \%$ have opted that family food supply is interrupted for 5 to 6 months every year. Majority (49\%) of them have responded that it is interrupted for about 3 to 4 months every year, and nearly $29 \%$ of them attested that food 
supply is discontinued for about 1 to 2 months every year as a result of climate change and its negative impact on households' livelihood sources.

\section{Food discontinuation period and percantage}

For 5 to 6 months For 3 to 4 months For 1 to 2 months

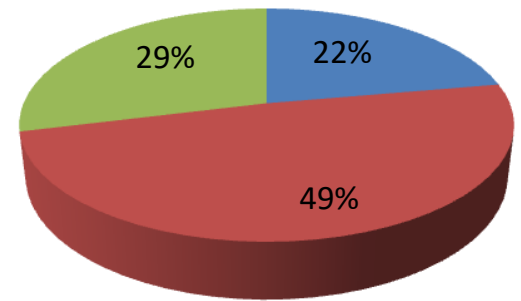

Source: Primary data

Figure 4.7: Food discontinuation period

One study conducted in the context of Southern region (Leulseged, et al, 2013) has also arrived on related conclusion that the food security of low-income households who were also registered under the safety-net program was interrupted on average for four to five years. This is in similar tune with current study though the target population of study and its parameters are somehow different. This finding is also confirmed by the FGD and the key individuals' interview. This indicates that the livelihood outcome of climate change is burdensome for large amount of the studied households.

\subsection{Regression and Correlation Analyses}

In this section, multiple linear regression analysis and correlation of major study variables to explore the effects of climate change on livelihood of subsistence farmers in the study area were carried out.

4.8.1 Regression Analysis: Regression analysis is good in predicting the effect of one variable on the other. Its importance is that it is used to predict the effects of the dependent variable on the independent variables. In line with this, the impact of the independent variables (that are perceived to be the causes of climate change: Rapid growth in population, Overgrazing, Deforestation for agriculture expansion, Burning of forest for charcoal, and Improper use of farmland) on the dependent variable, livelihood was assessed. The first table is the model summary. This table provides the $\mathrm{R}, \mathrm{R}^{2}$, adjusted $\mathrm{R}$, and the standard error of the estimate, which can be used to determine how well a regression model fits the data.

Table 10: Summary of Regression Model

\begin{tabular}{|c|c|c|c|c|}
\hline \multicolumn{5}{|c|}{ Model Summary } \\
\hline Model & $\mathrm{R}$ & R Square & Adjusted R Square & Std. Error of the Estimate \\
\hline 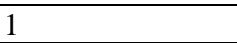 & $.339^{\mathrm{a}}$ & .115 & .077 & .689 \\
\hline
\end{tabular}

Source: SPSS Statistics Output

Table 11: Summary of ANOVA Analysis

\begin{tabular}{|l|l|l|l|l|l|l|}
\hline \multicolumn{2}{|c|}{ ANOVA } & Mean Square & F & Sig. \\
\hline \multirow{2}{*}{\begin{tabular}{l} 
Model \\
\cline { 3 - 8 }
\end{tabular}} & Regression & 7.209 & 5 & 1.442 & 3.040 & $.013^{\mathrm{a}}$ \\
\cline { 2 - 8 } & Residual & 55.490 & 117 & .474 & & \\
\cline { 2 - 7 } & Total & 62.699 & 122 & & & \\
\hline
\end{tabular}


Note: a. Predictors: (Constant), Rapid growth in population, Overgrazing, Deforestation for agriculture expansion, Burning of forest for charcoal, and Improper use of farmland.

a. Dependent Variable: Level of Livelihood

Source: SPSS Statistics Output

In this case, for change in livelihood, a value of $\mathrm{R}=0.339$ indicates the level of prediction. The $\mathrm{R}^{2}$, which is the coefficient of determination, which is the proportion of variance in the dependent variable that can be explained by the independent variables, is 0.115 . This shows that our independent variables explain $11.5 \%$ of the variability of our dependent variable, the level of livelihood. The F-ratio in the ANOVA results in table 10, F $(5,117)=3.040$, $\mathrm{p}(=0.013)$ which is $<0.05$

As it can be seen from the table 12, the unstandardized coefficient of each independent variable is not equal to zero in the population. Considering that all coefficients are different from zero, such as population growth predict a change of 0.098 units in livelihood, overgrazing predict a change of 0.222 units in livelihoods, deforestation predict a change of .070 units in livelihood, destruction of forest for charcoal predicted a change of -0.085 units in the livelihood and finally improper land use predict 0.100 units of change in livelihood.

Table 12: Output of Regression Analysis

\begin{tabular}{|c|c|c|c|c|c|c|c|c|}
\hline \multicolumn{9}{|c|}{ Coefficients } \\
\hline & \multirow[b]{2}{*}{ Model } & \multicolumn{2}{|c|}{$\begin{array}{c}\text { Unstandardized } \\
\text { Coefficients } \\
\end{array}$} & \multirow{2}{*}{$\begin{array}{c}\begin{array}{c}\text { Standardized } \\
\text { Coefficients }\end{array} \\
\text { Beta }\end{array}$} & \multirow[t]{2}{*}{$\mathbf{T}$} & \multirow[t]{2}{*}{ Sig. } & \multicolumn{2}{|c|}{$\begin{array}{c}\text { 95\% Confidence } \\
\text { Interval for B } \\
\end{array}$} \\
\hline & & B & $\begin{array}{c}\text { Std. } \\
\text { Error }\end{array}$ & & & & $\begin{array}{l}\text { Lower } \\
\text { Bound }\end{array}$ & $\begin{array}{l}\text { Upper } \\
\text { Bound }\end{array}$ \\
\hline \multirow[t]{6}{*}{1} & (Constant) & .745 & .436 & & 1.710 & .090 & -.118 & 1.608 \\
\hline & Population Growth & .098 & .070 & .123 & 1.403 & .163 & -.040 & .237 \\
\hline & Over grassing & .222 & .082 & .237 & 2.711 & .008 & 0 & .385 \\
\hline & Deforestation & .070 & .065 & .093 & 1.066 & .289 & -.060 & .199 \\
\hline & $\begin{array}{l}\text { Charcoal } \\
\text { production }\end{array}$ & -.085 & .077 & -.098 & -1.110 & .269 & -.237 & .067 \\
\hline & Improper land use & .100 & .051 & .173 & 1.986 & .049 & .000 & .201 \\
\hline \multicolumn{4}{|c|}{ a Dependent Variable: Livelihood } & & & & & \\
\hline
\end{tabular}

Source: SPSS Statistics Output

Note: a Dependent Variable: Livelihood

All of the above statistical findings indicate that the regression analysis of independent variables on the dependent variables have explained that there is weak statistical significance that the dependent variable is caused by the independent variables.

4.8.2 Correlations Analysis: The correlation analysis is used to find out the association (relationship) of independent variables to the dependent variable. Correlation is used to find out the relationship of the climate change effects on the livelihoods of farming households in this study area. The statistical data generated by the SPSS statistics is displayed in the table 13 for further analysis. As it can be seen from the table 13, all correlations are direct and statistically weakly significant. All of the Pearson product moment correlation coefficients are greater than 0.05. All correlations are week (between 0.01 and 0.24 ) according to most statisticians (Holcomb, 2006).

Based on the results, it can be concluded the regression analysis, that the dependent variables of the study only explain $11.5 \%$ (at a P-value of 0.013 which is less than 0.05 ) of the effect of climate change of the livelihood change in the study area. This shows that in general lower prediction of the model. Both the findings of regression and correlation maintain similar findings and are not contradictory. The week prediction of the regression model is mainly attributable to the study samples which are fewer as compared to the overall population of the district. 
Table 13: Output of Correlation Analysis

\begin{tabular}{|l|l|c|}
\hline \multicolumn{2}{|c|}{ Correlations } & \multicolumn{1}{c|}{ Depended Variable } \\
\cline { 2 - 3 } & & Livelihood \\
\hline \multirow{3}{*}{ Population Growth } & Pearson Correlation & .136 \\
\cline { 2 - 3 } & Sig. (2-tailed) & .134 \\
\cline { 2 - 3 } & $\mathbf{N}$ & $\mathbf{1 2 3}$ \\
\hline \multirow{3}{*}{ Overgrazing } & Pearson Correlation & $.228^{*}$ \\
\cline { 2 - 3 } & Sig. (2-tailed) & .011 \\
\cline { 2 - 3 } & $\mathbf{N}$ & $\mathbf{1 2 3}$ \\
\hline \multirow{3}{*}{ Deforestation } & Pearson Correlation & .101 \\
\cline { 2 - 3 } & Sig. (2-tailed) & .265 \\
\cline { 2 - 3 } & $\mathbf{N}$ & $\mathbf{1 2 3}$ \\
\hline \multirow{3}{*}{ Charcoal production } & Pearson Correlation & .069 \\
\cline { 2 - 3 } & Sig. (2-tailed) & .451 \\
\cline { 2 - 3 } & $\mathbf{N}$ & $\mathbf{1 2 3}$ \\
\hline \multirow{3}{*}{ Improper land use } & Pearson Correlation & .161 \\
\cline { 2 - 3 } & Sig. (2-tailed) & .076 \\
\cline { 2 - 3 } & $\mathbf{N}$ & $\mathbf{1 2 3}$ \\
\hline
\end{tabular}

Source: SPSS Statistics Output

Note: *significant at the 0.05 level (2-tailed).

\section{Conclusion and Recommendations}

Climate change is he global problem and affects most of the poor peasants' livelihood in the developing countries. The research findings also endorsed such problems in the study area which needs immediate attention. The livelihood problem in the study area is due to ever-increasing population growth, improper use of land, over grazing, shortage of agricultural land and decreasing soil fertility. Also farmers adaptation to the climate in the study area is limited by many factors including absence of good governance and community inclusive development, lack of awareness creation about climate change, its causes and adaptation scheme and lack of introduction of appropriate technologies. In addition, the result showed that most of farmers in the study area were unaware of the climate, livelihood strategies are affected with climate change. Based on the findings, following recommendations are forwarded for future improvements in adaptation of climate change and livelihoods development in the study area and in similar other localities.

- To create community dialogue between the public and private academic institutions, decision making government bodies and development partners to influence creation and implementation of effective policies regarding how to manage and curtail the problems of deforestation, land use, and livestock pasture management, as the implications of these on climate variability is so strong that only policy decisions that have local participation and consensus can make a significant difference in the future.

- The development agents working in the village level concerned with agriculture and livestock development work seriously with the local residents the plant and livestock varieties that can easily adapt to climatic variability and those which have strong resilience.

- Local non-government agencies also needs to work in introducing selective seeds and artificial inseminations in order to help the local community have better varieties of agricultural and livestock sources to improve their livelihood.

- The responsible government bodies found at Zonal, woreda and kebeles levels should consider these problems and include the need to create effective and equitable local governance in the new reform agenda for the coming decade. In this regard, it may be possible that the in the near future more inclusive development that can be responsive for climate change will be created at the study word's context.

- More water wells need to be drilled for human and livestock consumption. The district water resources and supply office needs to study the scope of the problems and implement remedial measures in collaboration with existing development partners which have similar development thematic areas.

- The reasons for failure of water harvesting program need to be studied by the district agricultural office and possible measures of reactivate the same. If this made functional, has a potential advantage in creating small-scale irrigation and could be source of water for livestock, which will in turn improve community's adaptation to climate change in the future. 
- Economic activities such as draught adaptive cereals and increase plantation of other draught resistant crops to respond to the problems of disruptions of food supply in the district.

\section{References}

[1] Barry, R. (2009). Changes in Mountain climate and glacier hydrological response. Mountain Research and Development, Vol.12 (1), p 783.

[2] Ellias Asgera (2010). A Survey of livelihood assistance and changes in southern region: The case of Hagereselam, SNNPR State, Unpublished Thesis.

[3] Habtamu Geleta (1999). Rainwater harvesting concepts and issues: Paper presented at the founding conference of the Ethiopian rainwater harvesting Association. December 17, 1999. Addis Ababa.

[4] Holcomb, Z. C. (2006). SPSS Basics: Techniques for a first course in statistics, Pyrczak Publishing. Glendale

[5] Holmgren and Oberg H. (2006). Climate Change in Southern and Eastern Africa during the past millennium and its implications for societal development, Environment, Development and Sustainability, Vol. 8. pp 185195.

[6] Institution for Social and Environmental Transition (2013). Simple Scaled Climate Projections \& Their Potential Implication for Jijiga, Ethiopia. Institute for Social and Environmental Transition-International Boulder, CO USA.

[7] Kindu M. (2013). Sustainable agricultural intensification and its role on the climate resilient green economy initiative in Ethiopia. Report of the 3rd national platform meeting on land and water management in Ethiopia, Addis Ababa

[8] Lemo District Agriculture and Natural Resources Development Office (2015). An annual review of the economic status of farming household in the woreda. Unpublished Official Material.

[9] Leulseged Tamire (2013). Climate change and agricultural development policy in Ethiopia. A study among households in Silte Zone of SNNPR State. Unpublished Thesis.

[10] Ministry of Finance and Economic Development (2010). Ethiopia building on progress: A plan for accelerated and sustainable Development to end poverty. Ministry of Finance and Economic Development, Addis Ababa.

[11] Ringler. C (2011). The Impact of Climate Variability and Climate Change on Water and Food Outcomes A Framework for Analysis.

[12] Sorhaug, A., K, (2011). Climate change impacts and adaptations among Ethiopian farmers - Case studies of SNNP, Tigray and Oromia; Master's Thesis submitted to the university of Adger (unpublished).

[13] Temesgen Tadesse and Dawit Mehari, (2010). Assessment of the vulnerability of Ethiopia agriculture to climate change and farmers' adaptation strategies of Pretoria, South Africa. 